\title{
“A gente não faz mais guerra, agora a gente está pensando": xamanismo e educação escolar entre os Maxakali'
}

\author{
Marina Guimarấes Vieira
}

\begin{abstract}
resumo $\mathrm{O}$ objetivo deste ensaio etnográfico é descrever algumas formas de relação dos Maxakali com a alteridade. $\mathrm{O}$ contato com os brancos é analisado em continuidade com a relação dos Maxakali com os inimigos e os espíritos. Guerra e ritual são compreendidos como diferentes momentos de um mesmo processo de predação e subsequente domesticação de potências exteriores necessárias à constituição do socius maxakali. Analiso a relação entre saber xamânico e educação escolar, sugerindo que, assim como os cantos rituais são usados para pacificar os espíritos, a escrita é usada para pacificar os brancos. A guerra - cuja prática tornou-se hoje praticamente impossível - é então atualizada no plano da cosmologia, do pensamento, nos contextos do ritual e da escola.
\end{abstract}

palavras-chave Maxakali. Guerra. Xamanismo. Ritual. Escola.

\section{Introdução}

Os Maxakali somam hoje aproximadamente 1400 pessoas, distribuídas em uma Terra Indígena e duas Reservas localizadas no vale do Mucuri, nordeste de Minas Gerais². Os moradores da Terra Indígena e das Reservas distribuem-se em várias aldeias que se mantêm em constante processo de reestruturação.

Nimuendaju (1958) classificou os Maxakali como um grupo isolado, do ponto de vista linguístico e cultural. Entretanto, pesquisadores como Popovich (1980), Greg Urban (2002) e outros afirmam que o maxakali é a única língua atualmente falada da família linguística maxakali, pertencente ao tronco linguístico macro-jê.

Os Maxakali se autodenominam tikmu'un - nós, humanos - e chamam 'ãyubuk os estrangeiros. Nas últimas décadas o contato com os brancos tem sido frequente, enquanto a relação com outros povos indígenas se tornou mais esporádica. Assim, o termo 'áyuhuk vem sendo usado principalmente como sinônimo de branco. O cosmos maxakali é povoado por muitos espíritos, chamados yâmiy ${ }^{3}$. Eles são a transformação do koxuk (alma) dos mortos maxakali e também do koxuk de outros seres. Na lista de yâmiy elaborada por Popovich (1976a) encontramos animais, plantas, acidentes geográficos, corpos celestes, artefatos, brancos e índios botocudos.

Para os Maxakali, humanos, animais e espíritos distinguem-se não em essência, mas através dos bens culturais atribuídos pelo demiurgo topa $a^{4}$. Os Maxakali dizem que, antes da inundação do mundo causada por uma grande enchente, animais, espíritos (inclusive topa) e humanos viviam todos juntos, compreendendo-se mutuamente. O mito conta que este dilúvio dizimou toda a humanidade, restando apenas um homem que se escondeu dentro do tronco oco de uma árvore. Topa salvou-o da fome e do frio, dando-lhe amendoins e bananas, e acendendo 
uma fogueira. Em seguida, apontou a direção para onde ele poderia andar e encontrar uma mulher. O homem perambulou sozinho pelo mundo até encontrar uma mulher da "nação" dos veados. Teve com ela alguns filhos veados, até conseguir fazer filhos humanos. Assim surgiu a humanidade atual, separada dos animais. Um Maxakali contou-me este mito ${ }^{5}$, concluindo-o com as seguintes palavras:

Então topa deu uma espingarda para o Maxakali, mas ele não soube atirar. Passou a espingarda para o branco, que atirou e guardou. Topa deu o arco e flecha para o Maxakali, que atirou. Se o índio desse um tiro, era 'ãyuhuk igual você, e estava rico até agora. Mas ele jogou a flecha, aí acabou a riqueza. Aí 'áyuhuk aprendeu tudo que é coisa de ferro.

Algumas passagens míticas (Popovich 1976b) contam como os Maxakali desperdiçaram dádivas de topa (como a espingarda ou uma lontra que os ajudava a pescar muitos peixes) e voltaram-se contra ele, atirando flechas em sua direção. Por estas razóes, topa resolveu abandoná-los na miséria, dando aos brancos o conhecimento das armas de fogo e do ferro. Assim os brancos passaram a viver na riqueza, na companhia de topa, hoje associado a Jesus.

O fragmento de mito transcrito abaixo descreve um episódio no qual um jovem maxakali tem a intenção de se aliar aos brancos através do casamento,mas seus pais recusam a aliança:

Dizem que havia uma branca que gostava do antepassado. Ele disse para a sua mãe: "eu vou me casar com a moça branca!" Mas dizem que o pai dele disse: "não, nós não estamos acostumados com a comida deles! Deixe essa moça pra lá. Você não vai se casar com ela”. O pai e a mãe não queriam o casamento. A moça branca continuou como ela era, e eles não se casaram. (Popovich, 1976b, p. 26, tradução minha)
A relação é aqui negada devido a uma incompatibilidade alimentar entre brancos e Maxakali. Mais uma vez, os antepassados fizeram uma "má escolha", permanecendo, portanto, na miséria.

Considerando o que foi exposto acima, penso que poderíamos compreender o discurso mítico maxakali sobre a distinção entre eles e os brancos como uma forma de antropologia maxakali sobre os brancos ou, nos termos de Roy Wagner (1981, p. 31), como uma "antropologia reversa”. Wagner nos ensina que uma cultura só aparece no confronto com a outra. É comum um antropólogo que inicia seu trabalho de campo sentir-se algo desnorteado. Ao aprender como agir em cada situação ou como lidar com as diversas pessoas, ele vai inventando uma cultura para o grupo estudado e contra-inventando para si sua própria cultura, até então invisível (Op. cit., p. 4). O autor observa que, na situação de contato com os brancos, os povos nativos viveriam constantemente uma versão mais forte de fieldwork (Op. cit., p. 31).

A partir do contato, os Maxakali não só elaboraram um conhecimento sobre os brancos, mas também reelaboraram aspectos de sua história, de sua relação com o demiurgo topa. Tal como o antropólogo descrito por Wagner, inventaram uma "cultura" para os brancos, contra-inventando, ao mesmo tempo, uma "cultura" para si mesmos. Mas esta "cultura" própria desvelada para o antropólogo em campo parece funcionar não como objeto a ser conhecido, mas como condição de conhecimento da "cultura" alheia. Tomando os Maxakali como "antropólogos" em constante situação de fieldwork (como índios em contato com brancos), apresento a seguir algumas notas sobre o complexo xamânico-guerreiro maxakali, no intuito de compreender algo sobre seu "fazer antropológico", ou seja, sobre sua forma de conhecer e se relacionar com os outros. 
“A gente Não faZ MAIS GUERRA, AGORA A GENTE ESTÁ PENSANDo" | I 37

\section{A guerra}

A leitura do trabalho de cronistas e antropólogos sobre a colonização do Mucuri deixa claro que, além da proximidade espaço-temporal, os povos falantes de línguas das famílias linguísticas maxakali e botocudo mantinham um mesmo "sistema xamânico-guerreiro", que era movido pela "predação da magia alheia" e visava à proteção do grupo de parentes das ameaças provenientes do exterior (Missagia de Mattos, 2002). O colonizador Teófilo Otoni relatou que os dois povos mantinham uma guerra centrada na vingança. Ele observou ainda que, em algumas situaçóes, os Maxakali aliavam-se aos brancos para combater seus inimigos tradicionais: "têm auxiliado constantemente os outros moradores na repressão dos Botocudos, cujas ofensas passam de pais à memória dos filhos" (Otoni, 2002[1858], p.92). A fala de um informante maxakali indica a persistência de uma memória sobre esta inimizade:

Monãyxop (antepassados) brigava com Imkox Xeka ("orelhas grandes" - df Botocudo). Um invadia a aldeia do outro, fazia guerra, e na hora da luta os yâmiy desciam e os Maxakali ganhavam. Se um morria, ficava o filho dele para vingar. A guerra não acabava. Aí chegou governo e ensinou que é tudo índio, que não pode brigar. Senão ia estar brigando até hoje.

Com o processo de colonização do vale do Mucuri, os territórios de caça e coleta foram se tornando cada vez mais raros, o que acirrou os conflitos entre os povos indígenas. $\mathrm{O}$ relato de um professor maxakali nos mostra como a prática xamânica orientava o sentido das migraçóes, antecipando a presença de inimigos:

Quando acabou a caça, as frutas, a madeira, tudo, os Maxakali resolveram se mudar para outro lugar. O pajé perguntou seus espíritos - o espírito chama o pajé de pai - onde era para ir. Os espíritos falaram baixinho para não ir ali, porque lá tem Botocudo armado esperando. Os Botocudo também perguntaram seus espíritos, que falaram dos Maxakali. Entáo os Botocudo invadiram a aldeia dos Maxakali. Teve luta, mas os Maxakali não lutaram. Foram os yãmiy que lutaram. Eles são mais fortes! É por isso que os Maxakali têm língua e vão ter sempre!

Nas palavras de um outro informante maxakali, "agora só tikmu'un é índio puro". Contou que, quando vai às reunióes do CIMI ou da Secretaria de Educação, os outros índios só falam em português, "não têm língua". Ao contrário dos Maxakali, que têm língua porque seus yâmiy são fortes, como observou o informante no relato acima. Segundo ele, uma moça branca disse para os outros índios: "vocês não têm língua, não são índios, os Maxakali têm língua, eles são índios de verdade!”. Comentou que "ãyuhuk (branco) náo gosta de índio sem língua”. A fala destes informantes indica que, além de se verem vitoriosos devido à conservação de sua língua, os Maxakali vêem as alianças que fazem com os brancos não como sinal de impotência diante de um inimigo, mas como sinal de poder, ao conquistar a aliança de um inimigo ainda mais poderoso que os próprios Botocudo.

Os Maxakali atuais parecem ter herdado uma memória a respeito de relaçóes com inimigos tradicionais mobilizada hoje para mover uma guerra atualizada na forma da disputa pela “autenticidade indígena”, alcançada através da prática ritual e do uso da língua, e propagandeada através dos CDs e livros de cantos e histórias em língua vernácula produzidos no âmbito da escola indígena ou de projetos de pesquisa e extensão das universidades.

Náo pretendo dizer aqui que todo o esforço maxakali de objetificar-se como cultura deva-se apenas a um antigo desejo de sobrepor-se aos 
seus inimigos tradicionais. Em sua situação de fieldwork, os Maxakali descobriram o conceito "ayyhuk (branco) de "cultura" e que, para os brancos, a vida ritual e o uso da língua vêm a ser a "cultura maxakali". Assim como no passado (quando prestavam serviços militares ou outros em aldeamentos), é preciso mostrar aos brancos que vale a pena deixá-los viver ou, nos termos atuais, que eles têm uma cultura singular e o direito de exercê-la. Um professor maxakali, que me contava sobre as pinturas corporais utilizadas pelos antepassados na guerra, comentou sobre os dias de hoje: "Nós não fazemos mais guerra, agora a gente está pensando.” Esta fala remete-nos às formas de atualização da guerra presentes nas práticas xamânicas e escolares, analisadas a seguir.

\section{Xamanismo}

Os yâmiy são agrupados pelos Maxakali em diferentes yämiyxop ( хор - grupo). De acordo com uma informante, "os yãmiy são como órgãos, tipo Funasa, Funai, Secretaria de Educação... cada música tem seu orguinho”. Durante os rituais taxtaxkox (lagarta da taquara) de iniciação masculina, os meninos são capturados por espíritos e passam um mês em reclusão no kuxex ${ }^{6}$, aprendendo sobre os yämiy. Segundo uma informante, o nome do espírito raptor passa a ser "como um sobrenome" para o menino, que deve aprender a cantar seu canto e a conduzir seu ritual, para assegurar a "posse" do yâmiy.

Cada grupo de parentes está ligado a um grupo de yâmiy._Aqueles que frequentam um mesmo kuxex ${ }^{7}$ e sempre realizam rituais juntos são chamados xape (parentes) e possuem o conhecimento de determinado conjunto de práticas rituais e cantos. Este repertório é um patrimônio familiar passado de geração para geração. Um canto é sempre propriedade de um vivente, mas esta propriedade é comparti- lhada com um yâmiy. Os Maxakali dizem, por exemplo, "o canto de mógmoka (gavião) é de Totó”.

A este antigo repertório são sempre acrescentados novos cantos, que trazem ao conhecimento novos mundos. Os cantos xamânicos são compostos por palavras em maxakali atual, em monáyxop äktux ("fala dos antigos" - palavras que não são usadas no cotidiano, ocorrendo apenas nos cantos e nos mitos) e vocalises. São algo como uma língua franca usada entre os homens e os espíritos, especialmente no que se refere aos vocalises. Segundo Popovich (1976a, p. 29), estes são sons que não pertencem ao quadro fonético maxakali. Alguns informantes já me disseram que estes sons são da língua do yâmiy dono do canto ${ }^{8}$. Muitos dos cantos são chamados, usados pelos viventes saudosos dos yâmiy. Outros sáo de despedida, cantados quando os yãmiy deixam a aldeia, cantos de "tristeza e saudade", como dizem os Maxakali. Pelas explicaçóes que eu recebia de meus informantes, estes cantos parecem remeter sempre a algo estrangeiro que, ao ser descrito e nomeado, torna-se familiar aos Maxakali'. Nos cantos os yämiy descrevem-se, falam dos caminhos que percorrem e contam sobre seus encontros com outros seres, às vezes imitando sua fala (assumindo sua perspectiva, poderíamos dizer). Quando Daldina Maxakali visitou comigo o Rio de Janeiro, recebeu um canto xamânico que, segundo sua traduçáo, dizia "fui pro Rio de Janeiro, subi na topa pet (topa-deus, Jesus pet-ninho, casa-referia-se ao Cristo Redentor), depois desci”. Falava do elefante, de como ele pega o capim com o "nariz" e coloca na boca para comer, de seus olhos bonitos e orelhas pequenas. Daldina disse:

eu aprendi esse canto com yâmiyhey (hey - feminino, estes espíritos são a transformação da alma das mulheres maxakali mortas), ela que me deu. Eu vou levar pra aldeia para meu pai cantar no 
yämiyxop (ritual), para os outros também ficarem sabendo como é no Rio de Janeiro ${ }^{10}$.

Novos cantos podem ser conseguidos através do contato com os outros em viagens, em expediçóes de caça (como contam os Maxakali sobre as memoráveis caçadas realizadas na companhia dos yámiy) ou na guerra. Recordemos o relato do informante maxakali sobre a guerra contra os Botocudo: “(...) O pajé perguntou seus espíritos onde era para ir. (...) Os espíritos falaram baixinho para não ir ali, porque lá tem botocudo armado esperando.(...)" Podemos supor que, assim como os animais mortos em caçadas, os Botocudo mortos pelos Maxakali na guerra passavam a ser seus espíritos auxiliares. Há inclusive alguns yâmiy que são almas de índios botocudo.

Como demonstrou Viveiros de Castro (2002a, p. 288), o que caracteriza a guerra ameríndia é a indistinção entre agressor e vítima, manifesta inicialmente como reconhecimento do outro como sujeito e posteriormente como processo de pacificação do outro. De acordo com a descrição de alguns cronistas, quando os grupos tupinambá capturavam um guerreiro de um grupo rival, este recebia uma mulher nativa e muitas vezes vivia anos entre seus captores, tornando-se parte do grupo de parentesco até chegar o dia de sua morte no terreiro ritual. A consumação da predação da potência inimiga se dava no consumo de sua carne. Ou seja, o inimigo era capturado e em seguida tornado parente ou "pacificado". Mas a memória da origem estrangeira do guerreiro capturado permanecia, o que permitia que o processo culminasse na predação de sua potência. É importante também lembrar que, como já demonstraram diversos autores da etnologia, a antropofagia pode ocorrer no nível simbólico, sem que haja necessariamente um ato de violência. Carneiro da Cunha (1993) observou entre os grupos jê a existência de uma "política de predação cultural" centrada na aquisição de rituais e cantos dos inimigos, dos espíritos - do exterior - que os permite expandir seu patrimônio. Nestes processos, que podem ser considerados uma variação da antropofagia (no nível simbólico), a memória sobre a origem estrangeira dos bens culturais adquiridos é observada.

Se para os brancos pacificar significa simplesmente reduzir o outro a um igual, desprovido de toda potência estrangeira, para os Maxakali e outros grupos jê pacificar pode significar igualar-se ao outro, imitá-lo, ocupar seu ponto de vista, podendo assim tornar-se sujeito de um conhecimento reconhecidamente alheio.

Nos mitos e nos comentários que eu ouvia dos Maxakali, os yâmiy aparecem como estrangeiros selvagens, pois tratam os Maxakali como presas. Por outro lado, possuem o conhecimento xamânico, que permite a obtenção de caça e cantos em abundância. Um mito contado para mim por uma informante maxakali ${ }^{11}$ mostra como os Maxakali foram "aculturados" pelos yãmiy, que os ensinaram a cantar e a construir um kuxex. Os homens aprenderam então a viver em aldeia, podendo assim realizar os rituais nos quais se encontram de forma segura com os yämiy ${ }^{12}$, compartilhando com eles os belos cantos. Por outro lado, o que a narradora do mito ressaltou para mim foi o fato de os yâmiy, que eram "brabos", terem sido "amansados" pelos Maxakali. Transcrevo abaixo trechos do mito:

Quando yãmiy viu o homem, deu uma flechada e levou nas costas para comer. Aí foi indo, foi indo, até que os índios amansaram yâmiyxop porque eles não fazem mais essas coisas. Se os antigos não tivessem amansado yãmiyxop eles estavam brabos até hoje.

É importante observar que foi através da predação do conhecimento dos espíritos - não através da violência, mas da imitação de seus cantos, da construção do kuxex - que esta "pa- 
cificação" dos yâmiy tornou-se possível. No ritual, ao entoar os cantos dos yâmiy, os Maxakali assumem seu ponto de vista, ou seja, tornam-se, também eles, sujeitos do conhecimento xamânico. Diante da impossibilidade de continuar praticando a guerra e a caça, restou aos Maxakali empregar sua política de "predação ontológica" (Viveiros de Castro, 2002b) no contexto xamânico. Talvez isso explique a intensidade de sua vida ritual.

\section{Ritual}

Quando um morto sente saudades de um parente vivo ele aparece em sonho e canta para tentar atraí-lo para junto de si. Esta é uma das principais causas da doença entre os Maxakali. $\mathrm{O}$ recolhimento em relação à vida social e à tristeza são sintomas da doença, que pode acometer uma pessoa insatisfeita com seus parentes e, portanto, mais vulnerável aos apelos dos mortos. $\mathrm{Na}$ verdade, a morte pode ser interpretada como uma mudança de aldeia, que acarreta o pertencimento a um novo grupo (não de pessoas humanas, mas de yãmiy) e uma mudança na relação com os parentes deixados para trás.

Quando alguém adoece, os moradores da aldeia devem fazer uma sessão de cantos para identificar o grupo ao qual pertence o yámiy causador da doença. No dia seguinte, devem providenciar os alimentos do gosto deste yámiy e cantar para atrair de volta o koxuk (alma) do doente e, ao mesmo tempo, convencer outros yámiy do grupo a levarem o morto saudoso de volta para o hãmnôy (hâm - terra, nôy - outra), onde vivem os espíritos. Durante o rito de cura os homens usam as armas do próprio yámiy agressor - seus cantos - na tentativa de pacificá-lo. Certa vez, ouvi de um informante maxakali um mito que conta como os Maxakali conseguiram, através de cantos, trazer de volta um parente que foi visitar a casa dos urubus e quase acabou virando um deles ${ }^{13}$.
A morte de uma pessoa - muitas vezes atribuída à falta de empenho dos parentes nos ritos de cura - pode fazer com que os ressentimentos entre os moradores de uma aldeia aflorem, levando as pessoas ao estado ungãy (bravo) e causando conflitos que podem provocar a dissoluçáo do grupo local.

O ritual, ao contrário da doença, é o motor da vida social. Quando perguntamos aos Maxakali porque eles fazem yãmiyxop (ritual), eles respondem simplesmente - hiptop! (alegria, cura, melhora). Cantar, dançar e compartilhar os alimentos com os yâmiy na aldeia deixa os Maxakali felizes. Eles afirmam que deixam suas casas de roça e reúnem-se na aldeia "para fazer yämiyxop". É por esse motivo também que fazem visitas prolongadas a parentes residentes em outras aldeias. Ao contrário da doença, caracterizada pela tristeza e pelo estado ungáy (bravo), o ritual produz o estado hiptop (alegre). Quando alguém se recupera de uma doença, os Maxakali dizem que a pessoa hiptop. Portanto, a alegria produzida pela vida ritual cura as doenças ou, dito de outro modo, fortalece os laços entre os parentes.

\section{Predação dos rituais ‘áyuhuk}

A política de predação ontológica exercida outrora em relação aos inimigos tradicionais e atualizada no plano cosmológico através da realização dos rituais é hoje exercida também em relação aos brancos. Quando adoecem, além de realizar seus rituais, os Maxakali recorrem aos enfermeiros da Funasa, aos benzedores regionais e pedem ajuda a Jesus.

Os Maxakali afirmam que já conheciam topa e Jesus quando os missionários do Summer Institute of Linguistics, Frances e Harold Popovich ${ }^{14}$, chegaram até eles. $\mathrm{O}$ próprio missionário fala sobre a existência de cantos xamânicos de topa, anteriores à sua chegada. Popovich (1976a, p. 30) transcreve um destes 


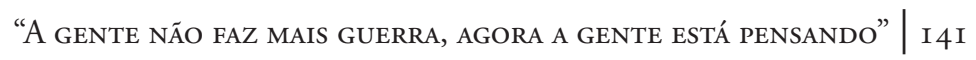

cantos e comenta que ele deixou de ser executado em contexto ritual. Um professor maxakali me contou que os yámiyxop (cantos xamânicos) e monãyxop yög ham äktux ("fala dos antepassados" - mitos) sobre topa e Jesus não foram ensinados pelos brancos, mas dados aos Maxakali por São Sebastiáo que, segundo ele, "é o mesmo que putuxop" (yãmiy papagaio). O professor cantou então o canto de putuxop e disse que era de São Sebastião. Explicou que "São Sebastião estava pousado num galho, aí flecha pegou ele". Sáo Sebastião é o santo padroeiro dos capuchinhos, que organizavam os aldeamentos indígenas durante a colonização do Mucuri. A imagem deste santo é de um homem com flechas cravadas no peito. Nos rituais de sacrifício aos quais pude assistir, foi sempre putuxop quem atirou as flechas no animal (geralmente um porco) a ser sacrificado. Se, como observou meu informante, São Sebastião foi flechado, talvez ele tenha sido morto por putuxop. Podemos imaginar que tenha ocorrido então uma "identificação" entre matador e vítima, manifestada através de uma "comunhão de cantos" (Viveiros de Castro, 2002a).

A missionária Frances Popovich conta que, em 1971, os Maxakali sofriam com a falta de alimentos e muitos se encontravam doentes. Resolveram então chamar Jesus, pois os rituais yãmiyxop náo estavam surtindo efeito. Nenhum informante concordou em contar a Popovich (1988) como Jesus foi chamado. Os Maxakali cantam hoje (apenas fora do contexto ritual, pelo que pude observar) várias cançóes sobre topa e Jesus em língua vernácula, ensinadas pelos Popovich. Estas são as traduções de um ancião maxakali dos cantos "do tempo de Aroldo" (Harold Popovich), por ele executados:

Tinha escuridão, mas com topa e Jesus o índio enxerga.

O sangue de Jesus fica no coração dos Maxakali, eles ficam alegres e não brigam um com o outro.
Se esquecer de Jesus fica ruim, mas se lembra de Jesus fica alegre, a pessoa não fica doente quando Jesus está no coração. Não briga, fica tudo bem.

Limpa meu coração Jesus, limpa meu coração Jesus.

Se esquecer topa, o coração fica escuro, aí lembrou de topa, limpa o coração, fica mai (bom, bonito), lembrou topa, fica mai, pode esquecer topa não, porque topa dá doença não, sarou, aí agora deu coraçáo, mai pra Jesus, gosta de Jesus, gosta de topa, pode esquecer náo, se esquecer, aí faz coisa ruim, aí coração fica escuro, ungãy (bravo).

Ele se chama Jesus, Jesus é xape (parente) todos nós irmãos, âyuhuk e tikmu'un, sangue de Jesus, nós todos parentes.

Esquecer-se dos yámiy - o que equivale a deixar de praticar os rituais - pode facilitar a entrada de um espírito ruim no coraçáo da pessoa, que fatalmente adoecerá. A tradução dos cantos acima nos mostra que se esquecer de topa e Jesus também pode causar o "escurecimento" do coração, ou seja, pode levar a pessoa ao estado ungãy, doentio. Mas lembrar-se de topa e Jesus, tê-los no coraçáo, contribui para a prevenção dos males causados pela entrada dos maus espíritos. F. Popovich observa que, após o episódio de 1971, os Maxakali diziam que a raiva que tinham em seus coraçóes havia sido substituída por amor e alegria. É sobre esta transformação que falam também os cantos de topa "do tempo de Aroldo", como dizem os Maxakali. Assim como os rituais yämiyxop (presença positiva dos espíritos), a presença de topa e Jesus "limpa" a raiva do coração dos Maxakali, fazendo com que as pessoas deixem o estado ungãy, caracterizado por conflitos e desunião, passando a um estado hiptop, no qual reina a alegria e a harmonia entre os parentes.

A conduta cristã de "amor ao próximo", ou seja, a generalização do parentesco, é afirma- 
da nos cantos transcritos acima e nos discursos maxakali sobre topa. Os Maxakali afirmam uma igualdade que lhes daria os mesmos direitos que os brancos, recuando sempre, porém, para a afirmação de sua diferença. Transcrevo abaixo trechos de uma carta dos Maxakali ao entáo deputado Mário Juruna:

Por que brasileiro mata os índios? Por que brasileiro tem cabeça e não tem miolo? Os índios tem miolo, nunca matou brasileiro. Índio tem dois pé. Brasileiro tem dois pé. Índio não é bicho. Nós somos irmão filhos de Deus. Quem fez nós? Topa. (...) O índio nasceu primeiro. Depois o civilizado. Por que brasileiro mata irmáo? Tá errado. (...) Nós tá procurando o direito nosso. (Cedefes, 1987, p. 92)

Ainda que desejada, a proposta cristá de generalização do parentesco é impraticável para os Maxakali. Apesar de desejarem experimentar o modo de vida dos brancos e suas vantagens, os Maxakali não querem completar o processo de transformação. Assim, o motivo pelo qual os Maxakali não aceitaram a conversão religiosa (eles afirmam que não são crentes e não realizam nenhuma forma de culto para Jesus) parece ser o mesmo que encontramos na recusa (atual e mítica) do casamento com os brancos: o desejo de conservar a diferença entre os dois povos para que o processo de reprodução social através da incorporação de potências estrangeiras não perca seu dinamismo, em outras palavras, para que seu "fazer antropológico" continue viável ${ }^{15}$. Mas, se os Maxakali nunca aceitaram uma igreja que acabasse por anular toda a diferença entre eles e os brancos, optaram por incorporar a escola.

\section{A escola}

Os relatos de colonizadores como Teófilo Otoni (2002 [1858]), bem como a etno-histó- ria produzida sobre os Maxakali deixam claro que, no passado, os missionários ofereciam aos Maxakali aldeados proteção em relação aos Botocudo - seus inimigos tradicionais - e aos colonizadores. A antropóloga Missagia de Mattos (2002, p. 84) observa que as autoridades não se interessavam em "instruir" os indígenas do vale do Mucuri devido ao frequente recrudescimento da violência - atribuído à índole falsa e inconstante dos índios - após tentativas aparentemente bem-sucedidas de pacificação. A tarefa de "civilizar" os índios recaía entáo sobre os missionários capuchinhos, que muitas vezes eram procurados pelos Maxakali em busca de proteção contra os Botocudo ou contra os brancos que, nos destacamentos militares, praticavam contra eles castigos físicos e outras formas de humilhação.

Durante quase trinta anos de trabalho missionário entre os Maxakali, Frances e Harold Popovich aprenderam a língua, analisaram-na fonética e fonologicamente e elaboraram um alfabeto. Traduziram o Novo Testamento para o maxakali, elaboraram cartilhas de alfabetização na língua indígena e, através da formação de monitores bilíngues, colaboraram com a Funai na implantação de uma escola bilíngue na Terra Indígena no início da década de 1980. Tinham o objetivo de converter os Maxakali ao protestantismo através da tradução de hinos e da bíblia para a língua indígena.

Os Maxakali parecem ter interpretado o projeto missionário como uma chance de estabelecer relaçóes mais simétricas com os brancos através da aquisição da escrita e da instituição escolar, e não de uma igreja, como queriam os Popovich. Quando um professor maxakali contou como topa diferenciou brancos e Maxakali através da atribuição de diferentes armas (arco e flecha/espingarda), aproveitei para perguntar sobre a origem da escrita, e ele disse:

Topa deu a escrita para o branco. Porque o branco acompanha Jesus direto, por isso topa deu a 


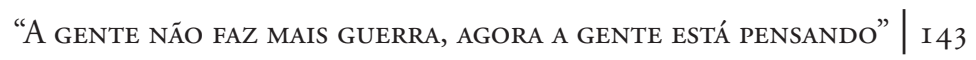

escrita para ele e ele aprendeu tudo. Jesus fez muitas coisas e deu para o branco. Jesus que deu a escrita para os 'áyuhuk, mas se desse para o tihi (homem maxakali), ele aprendia também, né, mas só deu para 'áyuhuk. Aí eu vi falando que ãyuhuk acompanha Jesus direto, por isso Jesus deu a escrita para 'ãyuhuk.

Em seguida, perguntei se Jesus era acompanhado só pelos 'áyuhuk, ou se andava também junto dos Maxakali. O professor disse que achava que "Jesus andou só com 'âyuhuk, mas ele era 'ãyuhuk e tikmu'un, porque sabia falar as duas línguas".

Auxiliados pelos Popovich, os missionários Adair e Zilene Gomes traduziram para o maxakali algumas das lições de evangelização sugeridas pelo livro Alicerces firmes, da $\mathrm{MNTB}^{16}$. Um informante mostrou-me algumas destas lições em maxakali. Pude compreender a pergunta "como acompanhar Jesus?" em um pequeno texto que dizia que, a mando de Jesus, os Popovich levaram a escrita aos Maxakali para que pudessem conhecer a palavra de deus. Então o informante maxakali contou-me algo sobre Adão e Eva, dizendo que, segundo os missionários, esta era também a história dos Maxakali. Logo em seguida, disse que "os Maxakali têm outra história”. Quando os missionários dizem que passagens bíblicas como a gênese também falam sobre a origem dos Maxakali, eles retrucam dizendo que "a história dos Maxakali é diferente". Mas, se Maxakali e brancos têm origens diferentes, certamente há um ponto em que suas histórias se cruzam, como nos mostra o trecho do relato de um informante maxakali, transcrito abaixo:

Aroldo escreveu a língua dos índios. Aí ele fez um livro e depois o mais velho (alfabetizado por Aroldo) morreu. Aí Totó me ensinou na tapet (papel). Depois tihi (homem maxakali) sabia escrever, aí passa para outro. Pessoal vem de fora,
Myriam. - Vou colocar professor aqui dentro da aldeia para ensinar criança, ensinar a ler na língua do tibi. Aí quando chama o tibi pra ir lá em Belo Horizonte aprender língua do português. Aí aprendeu língua de tibi aí passa pra português. Aí criança também aprende língua do pai dela aí passa pro português. Pode ser duas línguas. Primeiro não tinha branco, não tinha uma pessoa branca, tinha um tihi. Mas ele náo entende, quem vai ensinar estudar, tapet? Fazer tapet. Mas agora o branco saiu tudo assim, aí topa mandou. Topa mandou livro, colocou professor... Tihi também ficou pra professor, pra ensinar língua do tihi.

Tal como Jesus, os Maxakali agora podem falar as duas línguas. Este comentário sintetiza a visão dos Maxakali de si mesmos como seres duplos. No site www.caciosilva.com.br/ missiologica alguns missionários afirmam que, se fosse feita uma "eficiente abordagem", topa poderia ser aceito pelos Maxakali como deus de ambos os povos. Certamente, os cantos e as histórias sobre Jesus são, a princípio, cantos e histórias dos brancos. Mas podem ser captados e imitados pelos Maxakali, fazendo com que estes se identifiquem aos 'áyuhuk. Assim, topa pode até vir a ser considerado o deus de ambos os povos, mas terá que ser um deus duplo, um deus bilíngue ${ }^{17}$.

Conforme os mitos, topa teria abandonado os Maxakali porque eles desperdiçaram suas dádivas (como a espingarda ou a lontra pescadora) e fizeram uma má escolha - o arco e flecha. Os Maxakali ficaram pobres (a mata foi devastada pelos fazendeiros e a caça se extinguiu) enquanto os brancos, que teriam escolhido a espingarda, passaram a viver na riqueza, recebendo várias dádivas (o gado, os produtos feitos de ferro ou industrializados, a escrita, etc.) de seu deus. Mas, como dizem os missionários, e os próprios Maxakali, a escrita na língua vernácula foi a eles enviada por topa. Surge entáo uma 
possibilidade de reconciliação entre o demiurgo ofendido e os Maxakali que, sabendo aproveitar a dádiva, poderão desfrutar da mesma sorte que os brancos, como veremos adiante.

Os Maxakali utilizam metáforas do contexto xamânico para compreender o processo de ler e escrever. São feitas várias analogias entre escrita e canto, a começar pela traduçáo literal da palavra 'escrever' em Maxakali. Kax 'ambix significa, literalmente, "desenhar o canto"18. Conforme o Minidicionário Maxakali - Português de Charles Bicalho : "Kax - Pedir. Cantar. Som (de pássaro, de voz, de rádio...) Amix - riscar, desenhar".

Os Maxakali comparam frequentemente a escola ao kuxex, pois ambos são lugares próprios à transmissão do conhecimento advindo do exterior (a escrita vem dos brancos e os cantos vêm dos yämiy). Como já foi observado, durante o rito de taxtaxkox (lagarta da taquara) os meninos com idade em torno de sete anos são pegos pelos yämiy e levados para o kuxex, onde passam 30 dias sem contato com suas mães ou outras mulheres e aprendem coisas sobre os yãmiy.

A escrita é comparada ao mimkuin (ou taquara), instrumento mnemônico utilizado para a aprendizagem dos cantos xamânicos que consiste numa vara de bambu com vários tracinhos vermelhos. $\mathrm{O}$ aprendiz deve colocar o dedo num tracinho e cantar o canto correspondente, repetindo até acertar. Só depois pode passar para o próximo. Os Maxakali dizem que a taquara é um caderno, e os tracinhos feitos sobre ela com urucum são o $\mathrm{ABC}$. $\mathrm{O}$ u dizem simplesmente que a taquara é o $\mathrm{ABC}$ dos antepassados. Certo dia, um xamã maxakali raspou e pintou traços num pedaço de taquara que tinha trazido do mato. Ele disse que estava fazendo um mimkuin "para ensinar as crianças". Então pegou uma cartilha de alfabetização feita por Popovich e mostrou-me, chamando-a $m i$ mkuin, e dizendo que ela também servia para ensinar. Escreveu no chão as vogais - a, e, i, o, $\mathrm{u}$ - e disse “áyuhuk é assim”. Em seguida, dis- se "tikmu'un monãyxop (antepassado maxakali) é assim", apontando cada letra com uma varinha, parando e cantando. Pronunciou novamente cada vogal, mas dessa vez com o som correspondente ao alfabeto maxakali, e disse: "Doutor Aroldo (Harold Popovich) ensinou e eu virei professor". Mais tarde, o anciáo reuniu um grupo de crianças e cantou com elas utilizando a taquara para ajudá-las a memorizar uma sequência de cantos.

Os Maxakali chamam mimanã alguns padrôes geométricos aplicados em diversas superfícies: no mastro cerimonial que carrega este mesmo nome, no corpo, no papel. Cada padrão corresponde a um yámiyxop (grupo de yãmiy). Acredito que, para os Maxakali, a pintura funciona como um vetor de transformação da superfície onde é aplicada, como coloca Lévi-Strauss (1996 [1955]) em Tristes Trópicos, a propósito da pintura kadweu. Um mito maxakali ${ }^{19}$ conta como dois meninos foram feitos yãmiy através da pintura corporal. Assim como algumas características corporais dos animais são tidas como pinturas ${ }^{20}$ ou adereços, cada grupo de yãmiy tem um desenho característico como pele. Para a realização de cada ciclo ritual, um tronco é arrancado do mato por homens e yämiy, para ser pintado com o padrão correspondente ao yámiyxop a ser realizado - aos espíritos a serem chamados, aos cantos a serem entoados. Ao contrário do que poderíamos supor, a pintura aplicada ao tronco náo parece carregar um valor semântico, mas transformá-lo no mimaná, para que os espíritos possam, através dele, passar do hâmnóy ("outra terra”) para a terra dos humanos.

Os Maxakali usam o termo kax 'ambix para "desenhar" mimanã. É tentador relacionar os padrốes mimanã à escrita, sendo ambos o "desenho do canto". No entanto, os Maxakali nunca fizeram esta relação de forma explícita para mim, tal como fazem ao falar do mikuim (ou taquara), o $\mathrm{ABC}$ dos antepassados. 


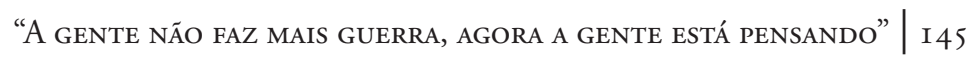

Nas escolas maxakali as crianças são alfabetizadas na língua vernácula pelos professores indígenas. Além disso, alguns anciãos foram contratados pela Secretaria de Educaçáo do Estado de Minas Gerais como "professores de cultura" para ensinar os cantos e mitos "tradicionais". Com exceção dos professores indígenas que fazem cursos de formação, apenas um grupo seleto de adolescentes e adultos maxakali estudam português e matemática com um professor branco. É fácil compreender a importância da escrita em português, diante da necessidade de lidar com a burocracia dos brancos. Mas a prioridade dada pelos Maxakali ao ensino da escrita em sua própria língua me intrigava, já que ela (na forma escrita) era muito pouco usada para a comunicação entre as pessoas no dia a dia.

Quando eu perguntava para que serve a escrita em maxakali, os informantes diziam "para não esquecer", referindo-se à língua, às histórias, aos cantos. Mas observam também que, mesmo não conhecendo a escrita, seus antepassados sabiam cantar e contar histórias. Afirmam ainda que o minkuim (taquara) continua sendo plenamente utilizado, e os pais, mães, tios(as) avôs e avós continuam contando histórias para as crianças. Durante uma aula, um professor maxakali escreveu no quadro este canto do mógmoka (gaviáo). Segundo ele, esta estrofe deve ser repetida substituindo-se os sufixos grifados, que designam diferentes tipos de gavião.

\section{Emôy mõg môkatap}

Yãy tu nû ne ãxup

$\hat{U g}$ tut xoppu yầtu nû ne

tap, xex, xầm, yôg, nok, nág.

O professor pediu para as crianças (já alfabetizadas) cantarem enquanto ele apontava as frases escritas no quadro. Os alunos, porém, ficaram em silêncio. Então ele escreveu a música num outro canto do quadro, do seguinte modo:

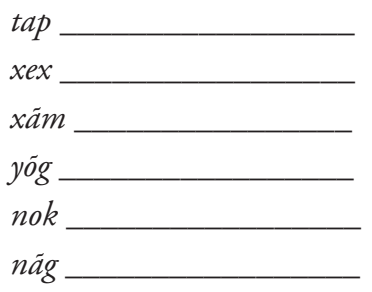

O professor ia apontando cada linha traçada e as crianças cantavam o canto do mógmoka usando um diferente sufixo a cada repetição. Apesar de o professor ter escrito a letra completa do canto no quadro, as crianças cantaram acompanhando apenas as linhas dos sufixos, pois, como ele observou, "lendo a música toda não estava dando certo”. As crianças só começaram de fato a cantar quando o professor usou um método de ensino semelhante ao mikuim, ou seja, utilizou as linhas como recurso mnemônico.

Os mitos também não são aprendidos através de sua leitura nos livros didáticos bilíngues. São contados pelos velhos (professores de cultura ou não) nas casas ou às vezes nas escolas, principalmente quando há a visita de algum branco envolvido com a "educação indígena". Houve uma única vez em que vi um professor usando um destes livros na escola. Só ele tinha o livro nas mãos, enquanto contava a história para os alunos com abundância de gestos, onomatopéias e alteração da voz para a interpretação de diferentes personagens. Depois tirou algumas palavras do texto para que os alunos copiassem.

Se os Maxakali afirmam precisar da escrita "para não esquecer", poderíamos ser levados a compreender a escrita em língua vernácula como um "novo suporte" para a conservação de uma memória e de uma tradição que já estariam lá ${ }^{21}$. Os livros bilíngues de cantos e histórias ajudam na alfabetização das crianças maxakali; porém, não são usados para ensinar as histórias dos antepassados e os cantos dos espíritos. Certamente, os Maxakali fazem uso da escrita como instrumento mnemônico quando trabalham com conhecimentos oriundos do 
mundo dos brancos, como os planos de aulas de alfabetizaçáo ou os cursos oferecidos pela Secretaria de Educação. Mas, para transmitir e memorizar o conhecimento proveniente dos yãmiy e dos antepassados, os Maxakali recorrem aos métodos "tradicionais" como a execução de danças e cantos no ritual, a narração dos mitos e a "leitura" do minkuim²2. A escrita também não atua na manutenção da língua maxakali como instrumento de comunicação entre as pessoas, pois esta - e apenas esta - é falada entre aqueles que se consideram tikumu'un - humanos verdadeiros.

Os professores maxakali são considerados donos de sua escola. Ocupam os prédios escolares como moradia e controlam todos os recursos recebidos para o seu funcionamento, como o material e a merenda escolar. Se, por um lado, os pajés ou yãmiytak ("pai dos yãmiy") controlam a realização dos rituais e o contato com os espíritos, por outro os professores de alfabetização controlam a realização das aulas e o acesso ao mundo dos brancos, pois são eles que contatam seus "patrocinadores".

$\mathrm{O}$ mito conta que os yâmiy ensinaram aos Maxakali como cantar e como construir o kuxex para a realização dos rituais. Vimos que hoje em dia os Maxakali usam estes mesmo rituais para contatar e pacificar os espíritos. Cantam para chamá-los e celebrar sua companhia ou para expulsá-los, promovendo a recuperaçáo de parentes doentes. Quando perguntei para a narradora do mito como os yâmiy haviam sido "amansados”, ela começou a falar sobre os Maxakali:

pra você ver... antigamente esses índios não tinham branco misturado, não tinham trabalho de professor... aí depois que amansou, começou a comer com sal, com óleo...

Para a informante o sal, o óleo e a escola (alusão ao trabalho de professor) figuram como signos da pacificação dos Maxakali. Mas, como vimos, a forma indígena de pacificação do outro é na verdade um deixar-se pacificar. Se os Maxakali podem imitar os cantos e ritos ensinados pelos próprios yãmiy para pacificá-los, podem também usar a escrita e a escola para pacificar os brancos.

Voltando à pergunta "para que serve a escrita?", encontramos outra resposta frequente dos Maxakali: "para poder assinar". Todos os adultos maxakali têm carteira de identidade indígena, título de eleitor e CPF, pois sabem da necessidade desses documentos para serem reconhecidos como cidadãos brasileiros, com direito aos benefícios concedidos pelo Estado. Como observou um dos professores maxakali: "tem que escrever, fazer documento, assinar embaixo e mandar para Brasília”.

Em 1982 ocorreram vários conflitos entre os Maxakali e os fazendeiros locais, que desejavam apoderar-se das terras indígenas. Foi organizada uma campanha contra os Maxakali através de uma série de atentados e reportagens falaciosas. Com a ajuda de "amigos" 23 , os Maxakali escreveram então uma carta ao presidente da Funai, esclarecendo sobre os artigos publicados contra eles no jornal Estado de Minas. Como a situaçáo permanecia a mesma, em 1983, os Maxakali decidiram recorrer ao então deputado Mário Juruna. Enviaram a ele a carta da qual transcrevi um trecho acima, que continha denúncias de agressóes e o mapa da terra que deveria ser demarcada (Cedefes, 1987).

Se os cantos e mitos são na realidade ensinados de forma "tradicional" - nas casas e durante os rituais -, penso então que a liçáo mais importante apreendida por professores e alunos das escolas maxakali é como lidar com a burocracia - que se dá via escrita - e, por consequência, como "pacificar" os brancos, fazendo-os passar de potenciais agressores a aliados, através de uma conscientização sobre os direitos indígenas (ou humanos) - sobre a igualdade de todos como filhos de topa. 
É importante lembrar que o complexo xamânico-guerreiro maxakali é movido pela predação (imitaçáo) da magia alheia, visando à pacificação dos inimigos e, consequentemente, à proteção do grupo de parentes das ameaças provenientes do exterior. No rito de cura fica muito claro esse tipo de operaçáo xamânica, pois é através dos cantos do próprio yãmiy agressor que um grupo de parentes pode vir a recuperar uma alma extraviada. Quando um doente se cura, os Maxakali dizem "ele hiptop" (melhorou). Os Maxakali afirmam sempre também que, com a escola, eles estão "melhorando”. Pode-se dizer então que os pares canto/ ritual e escrita/escola produzem um mesmo efeito sobre os Maxakali: a melhora, o estado hiptop. Através da escrita e da escola, os Maxakali podem reconciliar-se com topa, pacificar os brancos e conquistar uma "vida melhor", como dizem. E ter uma "vida melhor" significa viver na própria terra, sem a agressão dos inimigos, co-habitando com os parentes em paz, com harmonia e com alegria.

\section{Consideraçóes finais}

Num livreto ${ }^{24}$ bilíngue sobre um projeto de reflorestamento para a Terra Indígena, encontrei a seguinte fala de um Maxakali:

A mata acabou, mas temos nossos cabelos para morar nossos espíritos. A mata acabou. Mas temos nossas cabeças para guardar nossas histórias e para ensinar às crianças. ${ }^{25}$

Os Maxakali dizem que precisam da escrita "para não esquecer". Mas se nunca esqueceram seus cantos e histórias, guardados em suas cabeças, o que é que não podem esquecer?

Os Maxakali valorizam sua memória não como retrato de um passado estanque, mas como um projeto coletivo de continuidade histórica. Os Maxakali atuais teriam herda- do a memória da relação de inimizade com os Botocudo (e aliança com certos brancos), mobilizada para mover uma guerra atualizada na forma da disputa pela "autenticidade indígena”, alcançada através da prática ritual e do uso da língua e ostentada através de materiais bilíngues, que marcam a vitalidade da cultura maxakali e garantem diversas formas de apoio dos brancos ${ }^{26}$. Talvez seja plausível dizer que o que os Maxakali não podem esquecer é a forma pela qual o conhecimento - e as pessoas - devem ser produzidos: na prática relacional de predação ontológica. Se a escrita viabiliza a relação com os brancos, ela pode realmente servir "para não esquecer" como constituir um socius: na relação com o exterior._

Através da oferta de proteção em relação aos Botocudo e aos colonizadores e da oferta de seus conhecimentos, os missionários inauguraram uma nova forma de relação entre Maxakali e brancos. A escrita trazida pelos Popovich possibilita a reconciliação com topa. Este momento é considerado historicamente importante pelos Maxakali, como podemos atestar em narrativas como esta, que pude colher em campo:

(...) Antes os Maxakali tinham língua, mas não tinham escrita. Aroldo chegou aqui e comprou terra perto do Pradinho. Pagava os índios mais velhos, que sabiam, por um dia. (...) Aroldo ia escrevendo. Depois Aroldo voltou para a terra dele. Chegou Neli, professora da Funai, começou a ensinar. (...) Aroldo voltou com a cartilha. Ensinou Totó e mais uns outros e Totó virou professor. Fez uma casinha aqui, pediu quadro, e Aroldo trouxe. Depois Totó ensinou pros outros. Aí veio a Myriam e quem fez curso virou professor.

Ao fim de sua fala, o narrador acrescentou: "esta é a história dos Maxakali! Meu pai me contou e eu vou contar para os meus filhos". A aquisição da escrita e da escola é atribuída à aliança não só com os missionários, mas tam- 
bém com as antropólogas (Neli Nascimento, Myriam Alvares). Na verdade, só recentemente os Maxakali começaram a distinguir essas duas espécies de branco. Ao longo deste trabalho tentei descrever como os Maxakali vêm utilizando a escrita e a escola para a produção, num primeiro momento, de um conhecimento sobre os brancos - tal como antropólogos - e, num segundo momento, de um discurso para os brancos - tal como missionários - usado como alternativa às estratégias propriamente guerreiras.

Quando mostrei minha dissertação para um ancião maxakali, ele comentou: "Aroldo também escreveu uma cartilha". De forma semelhante, um Maxakali contou-me que fez uma viagem ao Rio de Janeiro junto de um padre e levou as cartilhas escritas por Popovich "para os brancos que moram longe ficarem conhecendo os Maxakali”. As cartilhas de alfabetização e a bíblia - um livro que conta a história dos brancos - foram os primeiros livros escritos na língua indígena e parecem figurar aos Maxakali como a ideia do que pode ser um livro. Algo que carrega histórias sobre um povo, algo que pode informar sobre um povo não para si mesmo, mas para os outros. Vários professores maxakali disseram que queriam escrever a "bíblia maxakali”. Quando eu perguntava em que língua esta bíblia seria escrita, eles respondiam: "tem que escrever em maxakali e em português, para os brancos verem que nós temos língua e história”. Através de livros bilíngues que carregam esta ideia de cartilha ou bíblia, os Maxakali buscam mostrar que, assim como os brancos, têm língua e história próprias e, portanto, direito à diferença e à continuidade histórica.

"We No Longer Make War, Now We Are Thinking": Shamanism and School Education among the Maxakali

abstract The objective of this ethnographic essay is to describe some Maxakali forms of relation to alterity. The contact with the whites is analyzed in continuity with the relationship of Maxakali with enemies and spirits. Warfare and ritual are understood as different moments of a single process of predation and subsequent domestication of exterior powers needed to the constitution of the maxakali socius. The relation between shamanic knowledge and school education is analyzed, suggesting that the writing skill is used to pacify the whites in a way analogous to that in which ritual chants are used to pacify the spirits. Warfare - the practice of which is almost impossible today - is thus actualized on the level of cosmology, thought, and in the contexts of ritual and the school.

keywords Maxakali. Warfare. Shamanism. Ritual. School.

\section{Notas}

1. Este ensaio é uma versão corrigida e ampliada de um trabalho apresentado no GT 14 da VIII Reuniáo da RAM em 2009. Agradeço os comentários dos participantes deste GT. Sou grata também aos professores Aparecida Vilaça e Eduardo Viveiros de Castro pela leitura, sugestóes e críticas. Responsabilizo-me, no entanto, por todas as ideias aqui expressas.

2. A Terra Indígena, localizada entre os municípios de Santa Helena de Minas e Bertópoles (já na Bahia), divide-se em duas glebas, Água Boa e Pradinho. Realizei trabalho de campo em Água Boa e na Reserva Aldeia Verde, no município de Ladainha, entre 2002 e 2007. A segunda Reserva maxakali, chamada Cachoeirinha, fica no município de Teófilo Otoni.

3. Optei por usar o termo "espírito" porque é esta a tradução mais frequente dada pelos Maxakali para o termo yämiy. Este pode designar também o canto (dos yämiy).

4. Estes bens culturais - alimentos, cantos, danças, características corporais, adereços, vestimentas ou técnicas específicas - devem ser compreendidos como conhecimentos que podem ser adquiridos ou perdidos.

5. Para uma versão mais completa e uma análise mais aprofundada do mito maxakali do dilúvio ver Popovich (1976b) e Vieira (2006).

6. "Casa de religião" no português falado pelos Maxakali. Local frequentado apenas pelos homens, por onde os espíritos devem passar ao entrar ou sair da aldeia. 
7. Cada aldeia possui um kuxex. No Minidicionário Maxakali/Português, Charles Bicalho (s/d) explica que, para se referir à aldeia, os Maxakali dizem "meptut te kuxex penãn" - "as casas estão olhando para a casa de cantos".

8. Certa vez, pedi a um informante que traduzisse para mim o canto que ele tinha acabado de executar. Ele disse "tem que passar da língua do yämiy pra maxakali e depois pra português".

9. Sobre a relação entre a nomeação das coisas e sua existência para os Maxakali, ver Vieira (2006).

10. No ano seguinte, quando visitei sua aldeia, perguntei a Daldina se ela se lembrava do canto do Rio de Janeiro. Então seu pai, que é xamã, começou a cantar o canto trazido pela filha.

11. Para uma versão completa do mito tal como foi narrado pela informante, ver Vieira (2006, p. 133-134).

12. Os Maxakali dizem que é perigoso encontrar um yámiy no mato ou em sonho. O lugar correto para o encontro com os yâmiy é no kuxex ou no terreiro ritual. Este encontro deve ser coletivo.

13. Para uma transcrição deste mito e uma análise mais aprofundada da problemática da doença, ver Vieira (2006).

14. Estes missionários trabalharam entre os Maxakali de 1959 a 1988.

15. Aparecida Vilaça (2000) relata uma situação semelhante entre os Wari. Apesar de terem optado por viver próximos aos brancos, experimentando tudo o que diz respeito ao seu mundo (comida, remédios, televisão etc.), os Wari recusam-se a casar-se com eles, o que viria a completar a identificaçáo entre ambos os lados. Para a autora, os Wari desejam manter os dois pontos de vista e, para isso, é necessário que os brancos permaneçam como inimigos.

16. Missão Novas Tribos do Brasil.

17. Em algumas versốes que ouvi do mito do dilúvio, topa aparece como um par de besouros. Popovich (1976a) afirma que há um topa ruim e outro bom. $\mathrm{O}$ autor afirma que o primeiro está sempre transformando o que o outro criou, enquanto este segue revertendo as coisas para sua forma original. Em alguns mitos maxakali sol e lua aparecem como um par de irmãos. O primeiro age sempre como demiurgo e o segundo como enganador. Para versóes destes mitos, ver Popovich (1971) e Alvares (1992).

18. Comunicação pessoal do linguista Charles Bicalho, estudioso da língua maxakali.

19. Para uma transcrição deste mito, ver Alvares (1992).

20. Os Maxakali fazem afirmaçóes como "a coral gosta de pintar assim com argila, jenipapo e urucum”.
21. Muitos brancos envolvidos em projetos de produção desse tipo de material bilíngue acreditam que a escrita possa vir a ser um "novo suporte" usado para garantir a "preservação cultural."

22. Os Maxakali usam o verbo monkupix (ler) em relação ao minkuim.

23. Provavelmente integrantes do CIMI, que nessa época auxiliavam os Maxakali na luta pela demarcação de suas terras.

24. Queremos a mata de volta! Povo Maxakali, CIMI-Leste, Universidade de Lavras.

25. O tema da estadia dos espíritos na cabeça ou nos cabelos das pessoas é frequente no discurso maxakali.

26. Seja na forma de políticas públicas dirigidas especialmente aos povos indígenas, através de projetos de ONGs ou do interesse de intelectuais e artistas pela cosmologia maxakali.

\section{Referências bibliográficas}

ALVARES, Myriam Martins. Yämiy, os espiritos do canto: a construção da pessoa na sociedade maxakali. Dissertação de mestrado - Universidade Estadual de Campinas, Campinas, 1992.

BICALHO, Charles. Mini-Dicionário Maxakali-Português / Português-Maxakali. s./d.

CARNEIRO DA CUNHA, Manuela. Les études gé. L'Homme, vol. 126-128, n XXXIII, p. 77-93, 1993.

CEDEFES - Centro de Documentação Eloy Ferreira da Silva. A luta dos indios pela terra. Contagem, 1987.

LÉVI-STRAUSS, Claude. Tristes Trópicos. Tradução de Rosa Freire D’Aguiar. São Paulo: Companhia das Letras, [1955] 1996.

MISSAGIA DE MATTOS, Izabel. Civilização e revolta: povos botocudo e indigenismo missionário na província de Minas. Tese de doutorado - Universidade Estadual de Campinas, Campinas, 2002.

NIMUENDAJU, Curt. Índios Machacari. Revista de Antropologia, vol. 6, n 1, p. 53-61, 1958.

OTONI, Teófilo. Notícia sobre os selvagens do Mucuri. Belo Horizonte: Editora UFMG, [1858] 2002.

POPOVICH, Frances. The social organization of the $M a-$ xakali. Dissertaçáo de mestrado - University of Texas at Arlington, Texas, 1980.

. Social power and ritual power in Maxakali society. Tese de doutorado - Fuller Theological Seminary, 1988.

POPOVICH, Harold. The Sun and the Moon, a Maxakali text. Summer Institute of Linguistics, 1971.

cadernos de campo, São Paulo, n. 19, p. 135-150, 2010 
I 50 | Marina Guimarães Vieira

Maxakali Supernaturalism. Summer Institute of Linguistics, 1976 .

. Maxakali myths on cultural distinctions and

Maxakali sense of inferiority to the national Brazilian culture. Summer Institute of Linguistics, 1976b.

URBAN, Greg. A história da cultura brasileira segundo as línguas nativas. In: CARNEIRO DA CUNHA, M. (Org.). História dos Índios no Brasil. São Paulo: Companhia das Letras, 2002. p. 87-102.

VIEIRA, Marina Guimarães. Guerra, ritual e parentesco entre os Maxakali: um esboço etnográfico. Dissertação de Mestrado - Museu Nacional, Rio de Janeiro, 2006.
VILAÇA, Aparecida. O que significa tornar-se Outro? Xamanismo e contato interétnico na Amazônia. Revista Brasileira de Ciências Sociais, vol. 15, n 44, p. 56-72, 2000.

VIVEIROS de CASTRO, Eduardo. A imanência do inimigo. In: (org.). A Inconstância da Alma Selvagem. Sáo Paulo: Cosac \& Naify, 2002a. p. 265-294. O problema da afinidade na Amazônia. In: VIVEIROS de CASTRO, E. (Org.). A Inconstância da Alma Selvagem. São Paulo: Cosac \& Naify, 2002b. p. $87-180$.

WAGNER, Roy. The Invention of Culture. Chicago: University of Chicago Press, 1981.

autora Marina Guimaráes Vieira

Doutoranda em Antropologia Social / MN-UFRJ

Recebido em 06/03/2010

Aceito para publicação em 20/09/2010

cadernos de campo, São Paulo, n. 19, p. 135-150, 2010 